\title{
ENERGY EFFICIENCY FINANCING INSTRUMENTS'
}

\section{A comparative Study}

\author{
Anikó Dobi-Rózsaª
}

\begin{abstract}
This paper develops a categorization of financial products supporting small-scale energy efficiency investments in fragmented markets where the end-users are not only capital-constrained, but also face the non-financial limitation of lacking a supportive institutional framework to implement energy efficiency investments. A defining common characteristic of small-scale energy efficiency investments is that they often require a third party that has the capacity to cluster these projects under one portfolio, presenting them as a single package to financiers in return for a share of the profit. In this framework of multiple stakeholders, if the financial incentives are unattractive, energy efficiency investments cannot happen. This paper explores how policymaking can play an effective role in addressing these non-financial limitations in fragmented markets, where a supportive institutional framework is lacking alongside capital constraints, in order to capture the multiple benefits of energy efficiency investments in the process of achieving global climate goals. The study devises a feasible set of policies for financing in capital-constrained, fragmented energy efficiency markets.
\end{abstract}

JEL codes: $\mathrm{G}_{2}, \mathrm{G}_{3}, \mathrm{G}_{4}, \mathrm{G}_{5}$

Keywords: climate finance, energy efficiency, energy efficiency finance, energy efficiency policy, financial instruments and products, financial intermediation, innovation

1 I would like to thank Dr. Dániel Havran for his valuable comments on this paper.

2 Anikó Dobi-Rózsa: PhD Candidate at Corvinus University of Budapest. E-mail: anikodobirozsa@gmail.com 


\section{ABBREVIATIONS}

AIIB Asian Infrastructure Investment Bank

BEERECL Bulgarian Energy Efficiency and Renewable Energy Credit Line

CEE Central and Eastern Europe

CEEF Commercializing Energy Efficiency Finance

CHUEE China Utility-based Energy Efficiency Finance

EBRD European Bank for Reconstruction and Development

EECR Energy-Efficient Construction and Refurbishment

EERSF Energy Efficiency and Renewable Sources Fund

ERDF European Regional Development Fund

EIB European Investment Bank

GEF Global Environment Facility

HEECP Hungary Energy Efficiency Co-Financing Program

IBRD International Bank for Reconstruction and Development

IEESP India Energy Efficiency Scale-up Program

IFC International Finance Corporation

KfW Kreditanstalt für Wiederaufbau (“Credit Institute for Reconstruction”)

OSS One-Stop-Shop business model

$\mathrm{PF}_{4} \mathrm{EE} \quad$ Private Finance for Energy Efficiency

REECL Residential Energy Efficiency Credit Line

RSEFP Russia Sustainable Energy Finance Program

SMEs Small and medium-sized enterprises

TuREEFF Turkish Residential Energy Efficiency Financing Facility

\section{INTRODUCTION}

Achieving the long-term temperature goal under the Paris Agreement (UN, 2015), to keep the increase in the global average temperature to well below $2^{\circ} \mathrm{C}$ above pre-industrial levels (and ideally to limit the increase to $1.5^{\circ} \mathrm{C}$ ), requires a $7.6 \%$ cut in global greenhouse gas emissions every single year for the next decade (UNEP, 2019). Furthermore, these projections clearly suggest that improving energy efficiency plays a vital role in combating climate change, and could account for over $40 \%$ of the greenhouse gas reductions pledged in the Paris Agreement (IEA 2019, 2018). However, current practice would need to be five times more ambitious in order to seize the untapped opportunities that energy efficiency offers (UNEP, 2019).

In Central and Eastern Europe (CEE), energy efficiency finance programmes implemented by international financial institutions, governments and commercial banks started more than two decades ago. The International Finance Corporation 
(IFC) pioneered the very first energy efficiency finance programme in Hungary, the Hungary Energy Efficiency Co-Financing Program (HEECP), followed by several replications implemented by the IFC and the International Bank for Reconstruction and Development (IBRD) in other CEE countries and later across the globe (IFC 2014; World Bank 2010; GEF 2004; 2002; 2001; 1997). Following this initial phase, many other European multilateral financial institutions followed suit (EIB 2019; EBRD 2019; 2013). These programmes were aimed at establishing and developing the energy efficiency market and reducing energy demand, improving efficiency and achieving additional positive environmental and social impacts as positive externalities. Their policy design aimed to build the capacity of energy efficiency lending and borrowing by offering grants to stimulate the growth of the energy efficiency investment market, while simultaneously reducing potential moral hazard risks attached to pure grant schemes via loan guarantees and preferential loans. Originally these programmes targeted all types of projects, although in practice this meant mainly larger infrastructural projects, but it soon became clear that the most challenging sector was the residential building sector (especially medium to low-income households), followed by the industrial SME and municipal sectors. During the development of these programmes, various innovative guarantees and finance products were developed to target these most challenging sectors, such as the widely published "portfolio guarantee." However, despite the relatively large volume of energy efficiency investments these programmes were able to generate, so far we have not witnessed a substantial upscaling in energy efficiency investments. Why this is the case remains an interesting open question.

The existing literature offers a clear understanding of the financial and non-financial limitations to energy efficiency (Levine et al., 2007), as well as reporting on the main policies generally applied to address some of these gaps. Capital-constrained end-users receive grants and interest rate subsidies (the latter especially in markets, particularly emerging ones, where interest rates are higher) aimed at encouraging them to implement energy efficiency measures. For financial institutions, some programmes offer financial guarantees to share or cover the real and perceived risks of energy efficiency finance (Czakó, 2012). Furthermore, where moral hazards and positive externalities exist, policies (if well designed) improve incentives for market players and serve as a catalyst for private finance (Berlinger et al., 2015). Rosenow (2017) also argues for a mixture of well-targeted policies in the field of energy efficiency finance. However, several questions remain unanswered, such as: What instruments actually work? And: What role does the state play?

It is commonly known that energy efficiency investments aim to reduce energy demand (or consumption) and improve efficiency (as in use) while achieving pos- 
itive environmental and social impacts (positive externalities in terms of various environmental and health benefits, in addition to a decrease in energy and fuel poverty). While measuring energy savings and greenhouse gas emission reductions is straightforward, other co-benefits of energy efficiency, although identified, are rarely quantified (Ürge-Vorsatz et al., 2014; 2009). A detailed review highlights that these co-benefits in buildings reach 19-43\% of saved energy costs (Ürge-Vorsatz et al., 2009). In order to capture these multiple benefits, governments arguably play an important role in supporting greenhouse gas emission reductions (IEA, 2014; Ürge-Vorsatz et al., 2008). Furthermore, for governments it is essential to understand how to measure and quantify these positive externalities because public funds allocated to address various environmental and social issues should not exceed the value of the broader benefits they bring to the public. Otherwise, public spending becomes unsustainable and difficult to justify.

In addition, while the available literature offers detailed discussions of the current limitations to energy efficiency investments, it rarely offers an order of priorities. This raises the question of whether it is possible that existing policies overlook some key issues or neglect to address them in the proper order, such as not paying enough attention to the importance of non-financial obstacles. For example, we know that energy efficiency markets are fragmented (Levine et al., 2007), and that to address this issue small-scale projects are often clustered under one portfolio by third parties (typically called "energy service companies") and presented to the financier as a single package. We also understand, however, that the energy service company model is not always suitable for the most fragmented of markets, such as the residential building sector, as there are not enough incentives for a private energy service company to operate in these markets. The question is thus how effective policies can provide incentives to address these market obstacles, stepping in where the energy service company model does not work without public funding. The importance of addressing the non-financial limitations to energy efficiency has recently started to come into focus in academic research (Rosenow, 2018). Nevertheless, further work is required to identify priority non-financial barriers and offer policy recommendations to address them.

Finally, the literature rarely discusses the concrete obstacles preventing successful rollout (replication) of energy efficiency programmes that already work. Many energy efficiency programmes cease to operate and advance once the specific financial subsidy is no longer available. Considering that these programmes typically involve a great degree of innovation, it is vital to look at supporting policies and see if any of the policies designed to support this innovative work can be adapted effectively in order to facilitate the replication of these innovative energy efficiency programmes. 
Within this context, the aim of this paper is to contribute to the existing literature by analysing twelve case studies of energy efficiency finance programmes, drawing lessons from them to fill in identified knowledge gaps in the energy efficiency finance and policy field. Our main research question will thus be: What is the effective level and form of state subsidies to support the scaling up of energy efficiency investments?

For the sake of simplification, this article focuses on the residential building sector, in light of the fact that in this sector $30 \%$ of projected greenhouse gas emissions can be avoided with a net economic benefit, outperforming the energy supply, transport, industry, agriculture, forestry and waste sectors in economies of transition (IPCC, 2007; Figure SPM.6, IPCC, 2007). From the case studies, we identify the technologies applied to save energy and the financial products put into place to finance various energy efficiency measures, with the aim of providing a classification based on which technologies and finance products are capable of scaling up energy efficiency. We identify what has worked so far from an environmental and financial point of view.

This paper argues that prioritizing non-financial obstacles, placing a special spotlight on the challenges represented by the very nature of fragmented markets and the ineffective framework of the institutional system, could help enhance current energy efficiency policies and support scaling up energy efficiency investments even in the most challenging sectors, such as residential buildings. In addition, the paper highlights that more research is required to identify priority barriers preventing the rollout of successful energy efficiency programmes on a large scale. Prioritizing (or reprioritizing) non-financial gaps could help to adjust current energy efficiency finance policies such as grants, interest rate subsidies and loan guarantees and facilitate the upscaling of energy efficiency investments. Furthermore, strengthening the framework of the (public) institutional system where market mechanisms (e.g. energy service companies) fail to deliver is vital if we are to achieve these goals.

This paper is structured as follows: first, we provide a detailed description of the selected case studies, the regions and timeframes in which they were/are active, the sources of their funding, the aims and sectors they targeted, and the technologies used. Next, we categorize the case studies based on the type, volume and scale of finance they offered, the level of involvement and coordination from the government's side in the distribution of financing, whether or not a focal point of distribution existed, and what was the level of involvement of the government in the focal point's daily operation. Afterwards, we will provide a matrix of energy efficiency programmes and policies used in current practices and offer policy recommendations to address the identified financial and non-financial barriers. Finally, we will conclude by illustrating the possible challenges of replicating the 
innovative EE finance products introduced in the earlier sections, and offer further policy recommendations to replicate these innovative finance mechanisms.

\section{DESCRIPTION OF CASE STUDIES}

For this research, twelve case studies were selected. The majority of the programmes were implemented in the member states of the European Union, and six in Central and East European countries. Outside of the European Union, case studies from Russia, Turkey, China and India were identified. The selected case studies targeted energy efficiency improvements mainly in residential buildings, with some extending to small and medium-sized enterprises (SMEs) and municipality assets.

The case studies included in this paper are mostly from emerging and developing economies since it is here that most of the support programmes targeted at energy efficiency in the residential and SME sectors by international (and sometimes national) development agencies, development banks and other actors are implemented. Although there are other EE support programmes in emerging and developing economies that are not included in this study, for example in South America, these are either at an early stage or lacking evaluation studies from which to collect data. As such, this study is limited to what is currently available in terms of reliable data and by the ad hoc nature of these support programmes, which were - and are being - introduced across various regions in an uncoordinated fashion.

The twelve programmes were operational between 1997 and 2020. Some are still in operation, but expected to end in 2022. Eight of the programmes were operational for between five and nine years, while the remaining four programmes ran for over a decade, for periods of between ten and sixteen years. In the pilot phase, between 1997 and 2004, only three programmes were launched; among these, the Hungary Energy Efficiency Co-financing Program, phase 1 and phase 2 (HEECP 1-2), was the sole programme in operation until 2002 (GEF, 1997; 2001; IFC, 2011). Later, between 2005 and 2019, five to seven different programmes were implemented in parallel. By 2019, the majority of the programmes had closed in Europe. As of today, only three programmes are ongoing in Turkey and India (EBRD, 2019; World Bank, 2018; 2019; TuREEFF, 2018). 
Figure 1

Energy Efficiency programme case studies, between 1997 and 2022

\begin{tabular}{|c|c|c|c|c|c|c|c|c|c|c|c|c|c|c|c|c|c|c|c|c|c|c|c|c|c|c|}
\hline Country & $\begin{array}{c}\text { Year / } \\
\text { Program }\end{array}$ & 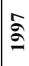 & $\stackrel{\infty}{\circ}$ & Әे & సั. & 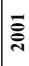 & సิ్ㅊ & ڤิ & ثั๋ & ڤั) & 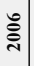 & ڤิ) & 离 & ڤેेે & อั & $\overline{\overline{\mathrm{N}}}$ & : & 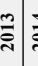 & 壳 & 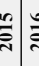 & 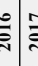 & 5 & : & సิ & $\bar{\Xi}$ & సี \\
\hline 1 Hungary & HEECP 1-2 & & & & & & & & & & & & & & & & & & & & & & & & & \\
\hline $3 \mathrm{CEE}$ & CEEF & & & & & & & & & & & & & & & & & & & & & & & & & \\
\hline 4 Bulgaria & BEERECL & & & & & & & & & & & & & & & & & & & & & & & & & \\
\hline 5 Bulgaria & EERSF & & & & & & & & & & & & & & & & & & & & & & & & & \\
\hline 6 Bulgaria & REECL & & & & & & & & & & & & & & & & & & & & & & & & & \\
\hline 7 Russia & RSEFP & & & & & & & & & & & & & & & & & & & & & & & & & \\
\hline 8 China & CHUEE & & & & & & & & & & & & & & & & & & & & & & & & & \\
\hline 9 Germany & KfW EECR & & & & & & & & & & & & & & & & & & & & & & & & & \\
\hline 10 Estonia & KredEx & & & & & & & & & & & & & & & & & & & & & & & & & \\
\hline $11 \mathrm{EU}$ & PF4EE & & & & & & & & & & & & & & & & & & & & & & & & & \\
\hline 12 Turkey & TuREEFF & & & & & & & & & & & & & & & & & & & & & & & & & \\
\hline 13 India & IEESP & & & & & & & & & & & & & & & & & & & & & & & & & \\
\hline
\end{tabular}

Source: compiled by the author from the case studies

Twelve programmes received nearly USD 24 billion funding in the period 19972018 and were successful in leveraging approximately USD 365 billion in energy efficiency investments during this time. The majority of funding was received by the programmes in the form of loans from supra-governmental international financial institutions for the approximate volume of USD 2.4 billion, and by the Federal Government in Germany for the approximate volume of USD 21 billion (KfW, 2017). Altogether, eight programmes received funding in the form of loans. By comparison, eleven of the twelve case studies received funding in the form of grants, including loan guarantees and technical assistance for the total volume of approximately USD 560 million. Only two programmes received national government grants, for the volume of USD 40 million.

As shown in Figure 2, from the case studies we can identify three major categories of fund provider at the national, supra-governmental and multilateral institutional (international financial institution) levels. The Federal Government in Germany and national governments provided funds in the form of grants and guarantees; the European Union (EU) and its member states provided grants, for example, through the LIFE programme ${ }^{3}$ or the European Regional Development Fund (ERDF) in the case of the EIB-PF4EE and Estonian KredEx ${ }^{4}$ programmes

3 The LIFE programme is the EU's funding instrument for the environment and climate action, created in 1992.

4 KredEx is the Estonian Credit and Export Guarantee Fund. 
(EIB, 2019; KfW, 2017; 2018; Build Up, 2017; Adler, 2013; World Bank, 2010). The European Investment Bank (EIB), the European Bank for Reconstruction and Development (EBRD) and the Council of Europe Development Bank provided loans (EIB, 2019; EBRD, 2019). The Global Environment Facility (GEF) and international financial institutions such as the International Bank for Reconstruction and Development (IBRD, known as the World Bank), its private sector arm the International Finance Corporation (IFC) and the Asian Infrastructure Investment Bank (AIIB) provided loans, guarantees and grants (World Bank, 2010; GEF, 1997; 2001; 2002; 2004). We note here that, in the case studies, the GEF typically channelled its funding through the IBRD and IFC.

\section{Figure 2}

\section{Funding structure for energy efficiency programmes}

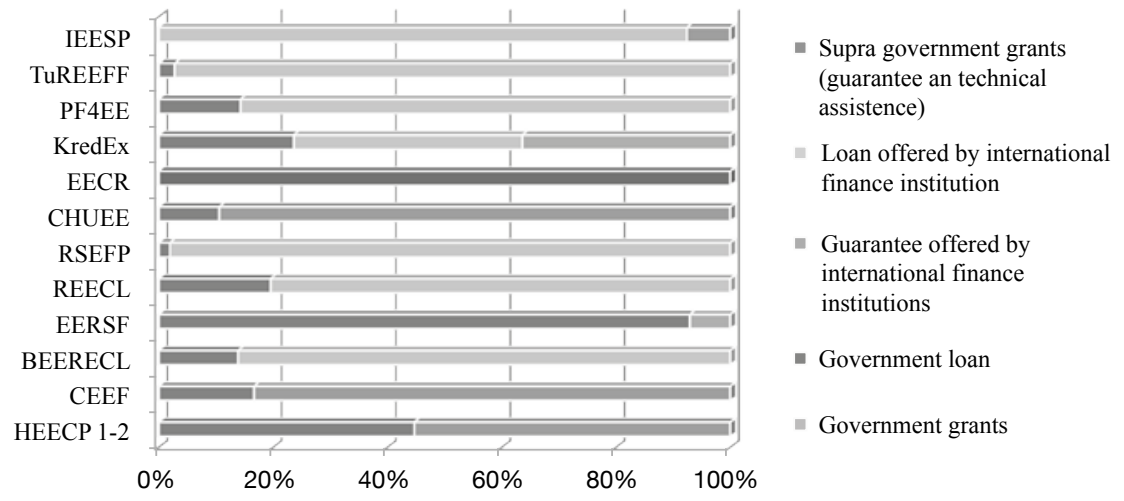

Source: compiled by the author from the case studies

The overall common aim of financiers was to overcome existing limitations to energy efficiency project financing by reducing the credit risk on energy efficiency lending for eligible local financial intermediaries. Furthermore, they aimed at facilitating longer lending terms than those typically offered on a purely market basis, providing targeted technical assistance, reducing the transaction costs borne by project participants, building a sustainable market-based capacity for developing and commercially financing energy efficiency projects, demonstrating financial profitability on energy efficiency investments, and promoting the development of a well-functioning energy efficiency market, involving the whole supply chain. The GEF specifically focused on mitigating climate change, while the EU promoted alignment of national policies with EU directives meant to reduce greenhouse gas emissions by 2020 and beyond. The funding providers specifically promoted high-standard energy efficiency technologies and the use of de- 
centralized or domestic renewable energy technologies (GEF, 2012; World Bank, 2010). Typically, the programmes targeted small-scale residential and industrial projects implemented by SMEs.

The case studies show that similar or nearly identical energy efficiency technologies were applied in the studied programmes (UN, 2020; GEF, 2004; 2012; IFC, 2011). However, due to a lack of post-implementation energy audits, the level of energy savings achieved was not always documented, and therefore not reported. Case studies also show that in some cases the programmes offered incentives for end-users achieving higher levels of savings than the end-user's own ambition (KfW, 2017; 2018). Although grants might have been able to address energy efficiency ambitions, only proven and widely used energy efficiency technologies were employed when commercial lending was involved, which might have hindered potential saving results. In addition, complex energy efficiency measures to achieve higher levels of savings were promoted mostly or only in the later phases of development of energy efficiency programmes. For this reason, we believe the energy efficiency potential was not fully realized.

Participating commercial financial institutions marketed the loans typically as energy efficiency loans, or in some specific cases as home refurbishment loans targeting residential buildings in general. There are also examples where the loan product's name was more specific, as in the case of "gas boiler" loans, where small loans were provided to residents in order to help them switch from coal-fired to gas-fired boilers in rural areas.

\section{CATEGORIZATION OF PROGRAMMES}

In these case studies, energy efficiency programmes employed three major financial instruments: commercial loans, credit risk-sharing facilities (guarantees), and grants. Figure 3 below shows that the majority of the funds were distributed to residential, SME and municipal end-users in the form of commercial loans, whereby each programme had a commercial loan element. Furthermore, all twelve programmes also had a non-refundable grant element. Finally, seven of the twelve energy efficiency programmes provided guarantees as cash collateral for risk sharing. 


\section{Figure 3}

\section{Energy efficiency finance products in the case studies}

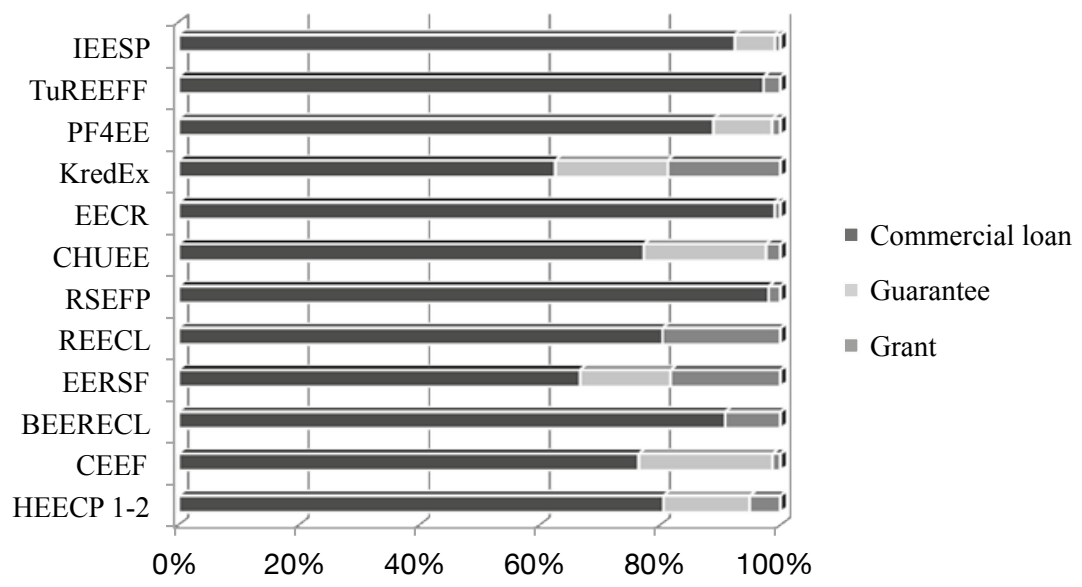

Source: compiled by the author from the case studies

Based on the above, we identified three categories of energy efficiency finance programmes. The first category applied commercial loans (including soft loans) to finance energy efficiency projects (KfW, 2018; EBRD, 2013; 2014; 2019). The second category employed a risk-sharing facility as a guarantee element (EBRD, 2013; Adler, 2013; IFC, 2011; World Bank, 2010). The third category offered nonrefundable grants. 
Table 1

Categorization of programmes based on type of funding provided

1. Commercial loan

Countries and programmes

Bulgaria (BEERECL, REECL)

Germany (EECR)

Turkey (TuREEFF)

2. Guarantee

Countries and programmes

Guarantee provided by international financial institutions:

Hungary (HEECP1-2)

Czech Republic, Estonia, Latvia, Lithuania, Slovakia (CEEF)

Russia (RSEFP)

China (CHUEE)

India (IEESP)

EU LIFE guarantee:

EU member states (PF4EE)

National governmental guarantee:

Bulgaria (EERSF)

Estonia (KredEx)

3. Grant

Countries and programmes

All programmes had a grant element

Source: compiled by the author from the case studies

\subsection{Commercial loan}

All of the cited energy efficiency programmes provide loans to end-users, albeit using different models, with international financial institutions providing credit lines to eligible commercial banks in the target countries for on-lending to residential, SME and municipality end-users (eligible sub-borrowers) for implementing energy efficiency projects. In one case, the IBRD made available a credit line to the national government of India, while in another case the Federal Government of Germany provided funding to the German development bank KfW for on-lending to eligible borrowers at low interest rates, with the possibility of partial debt relief according to the energy efficiency level reached. In two cases - in Estonia (KredEx) and Bulgaria (EERSF) - public entities established specifically for the energy efficiency programme in question distributed the loans (BuildUp, 
2017; EERSF, 2018). Where international financial institutions provided the credit lines, they typically determined only broad eligibility criteria for participating commercial banks. For example, the international financial institution decided which sectors (residential, SME, etc.) could benefit from the sub-loans. However, the commercial banks themselves were responsible for assessing the sub-loan applications and selecting creditworthy sub-borrowers who also had to meet the general criteria provided by the international financial institutions within the framework.

Similarly, in cases where commercial banks received guarantees and not credit lines from international financial institutions, the coordinators were commercial banks without direct governmental involvement. In this case, the commercial banks decided who received the loans and on what terms. The KfW model was similar to the international financial institutions' model, except that KfW acted as both an international financial institution and a commercial bank. In the German programme, KfW as a federal governmental development bank was in charge of allocating loans to end-users. In Estonia and Bulgaria, a specific public fund (the KredEx Revolving Fund and EERS Fund, respectively) was established to deliver loans directly or indirectly to end-users. These funds were individual legal entities; however, they were owned by the government. EERSF was managed by a ministerial department in Bulgaria, while the KredEx Revolving Fund is a government-owned non-profit provider in Estonia (EERSF, 2018; BuildUp, 2017). Therefore, in these two cases we can also see direct national governmental involvement in the process of loan distribution. In India, where the IBRD provided direct funding to the government, the highest level of governmental influence was identified alongside no involvement of commercial banks at all.

\subsection{Guarantee}

In these programmes loan guarantees were provided by international financial institutions in most instances, and in some cases by national governments. Guarantee instruments took different forms: from 1997 onwards, mostly first loss guarantees were offered, in some cases up to $50 \%$ of the loan value, in order to build confidence towards financing energy efficiency projects; later on, fund providers reduced the percentage of guarantee coverage while keeping the first loss component (GEF, 1997; 2001; 2004). In the more developed phases of the programmes, pari-passu guarantees were widely used as energy efficiency finance markets became more commercialized and commercial banks were more willing to share the risk of energy efficiency lending (World Bank, 2010; GEF, 2004). In some programmes (for example HEECP in Hungary, KredEx in Estonia, EERSF in Bulgaria), an innovative guarantee instrument was developed where the fund 
provider took the first loss guarantee on a small percentage (typically 5\%) of the total energy efficiency loan portfolio, while above this threshold all risks were shared equally between the commercial lender and the fund provider (IFC, 2011). This was referred to as a "portfolio guarantee." Overall, the case studies portray a gradual development of loan guarantee products over decades. For loan guarantees, funding providers charged negligible fees well below market rates.

In terms of how the guarantee programmes were managed, we can see two models emerging from the case studies. Where the IFC provided the guarantee, a designated IFC programme office and a programme manager employed by the IFC was responsible for coordinating and administering the guarantee programme. In the second model, a national agency (for example, the Estonian KredEx) was responsible for coordinating and administering the guarantee.

\subsection{Grant}

Non-refundable grants typically took the form of technical assistance, in order to increase the project development capacity on the market, and in some cases covering operational costs (administrative and staff costs). Technical assistance in the form of small-scale grants is typically provided to carry out energy audits, organize training for officers of commercial banks, awareness raising, etc. Grants were also used to provide revolving financing and loan guarantees (in Bulgaria: EERSF) (Citynvest, 2015). Apart from technical assistance, non-refundable grants were provided in the form of capital as an incentive where higher levels of energy savings were achieved (KfW programme).

The most important factor when it comes to attracting investors in energy efficiency is to have successful project implementation. In order to succeed, the best available technology has to be employed, which provides the highest value in terms of energy savings at the lowest cost. Grants, providing technical assistance, can address this issue via building capacity, covering the costs of energy audits, and the costs of engaging with manufacturers and distributors of energy efficiency technologies. Projects with lower success potential require a higher capital investment upfront from end-users. Therefore, where the policymaker provides grants to increase the success potential, the capital requirement is lowered, which encourages residential, SME and municipality end-users to invest in energy efficiency. 


\subsection{Balance of commercial loans, guarantees and grants in the case studies}

The programmes included as case studies offered loans with added enhancing elements such as guarantees and grants, which included technical assistance. The motivation behind this policy intervention was to address the asymmetric information problem when financing energy efficiency in the residential, SME and municipal sectors. In these sectors the financier generally does not have enough quality information on the future behaviour of the end-user, nor on whether the end-user is committed to succeeding with the energy efficiency project, and hence may be reluctant to finance energy efficiency projects in these sectors. The greater the scale of the asymmetric information problem, the more upfront capital is required from the borrower, which the residential, SME and municipal sectors may not be able to provide. Loan guarantee products are aimed at addressing this issue by sharing the risk of financing and reducing the cost of lending, which in turn can further reduce the risk of default.

In summary, seven out of twelve case studies combined a commercial loan with guarantees and grants, while five case studies used only commercial loans with grants, without guarantees. As outlined above, all the programmes involved grants and more than half used guarantees. We conclude that the policymaker aimed to simultaneously address the moral hazard issue and asymmetric information problem by combining a commercial loan in most cases (seven out of twelve) with both a grant and guarantee element.

\subsection{Programmes' level of coordination in loan distribution}

The case studies show that, where commercial banks were involved in the distribution of loans, the government's level of direct involvement in coordination and implementation was low; on the other hand, where loan distribution was organized by the government or a federal government bank (such as in the KfW programme), the involvement of government in coordination and implementation was clearly high. International financial institutions' credit lines from the EBRD and the EIB, for example, were implemented through commercial banks and through loans distributed via commercial banks, which did not require government involvement. Even the energy efficiency funds in Estonia and Bulgaria involved only moderate governmental coordination in implementation. Here, the loans were distributed through commercial banks with the coordination of public entities. The programmes implemented by international financial institutions and IFC programmes displayed the profile of a market-based horizontal approach, while the federal and national governmental distribution programmes 
represented a top-to-bottom approach. Energy efficiency funds where the coordination was organized through a public body usually linked to the national government or a ministry can be considered to have adopted a hybrid approach.

Table 2

Scaling of programmes based on coordination of loan distribution

\begin{tabular}{ccc}
\hline Categories & $\begin{array}{c}\text { Involvement of commercial } \\
\text { banks in coordination } \\
\text { and implementation }\end{array}$ & $\begin{array}{c}\text { Direct government } \\
\text { involvement in coordination } \\
\text { and implementation }\end{array}$ \\
\hline $\begin{array}{c}\text { Credit lines from } \\
\text { international financial } \\
\text { institutions (e.g. from } \\
\text { the EBRD or EIB) }\end{array}$ & Yes & $\begin{array}{c}\text { No } \\
\text { (no involvement) }\end{array}$ \\
\hline $\begin{array}{c}\text { IFC guarantee programmes } \\
\text { (HEECP, CEEF, etc.) }\end{array}$ & Yes & No \\
\hline $\begin{array}{c}\text { Energy efficiency funds } \\
\text { (KredEx, EESRF) }\end{array}$ & Yes & Yes + \\
\hline $\begin{array}{c}\text { Federal government } \\
\text { development banks (KfW) }\end{array}$ & No & $\begin{array}{c}\text { Yes ++ } \\
\text { (moderate involvement) }\end{array}$ \\
\hline $\begin{array}{c}\text { Government loans } \\
\text { (in India) }\end{array}$ & No & $\begin{array}{c}\text { Yes +++ } \\
\text { (medium-level involvement) }\end{array}$ \\
\hline
\end{tabular}

Source: compiled by the author from the case studies

Seven of the twelve case studies used the combination of commercial loan, guarantee and grant. Four of the seven programmes fall into the category where there was no direct involvement from governments in coordination and implementation of the programme (IFC guarantee programmes and the EIB programme) (EIB, 2019; IFC, 2011). Two case studies of the seven displayed moderate government involvement $(+)$ in coordination (KredEx, EERSF) (Citynvest, 2015), while one programme combined all three instruments (loan, guarantee and grant) and displayed strong direct $(+++)$ involvement of the national government in coordination and distribution of energy efficiency loans. This shows that programmes where loans, guarantees and grants are combined can be implemented successfully with different levels of participation in coordination and implementation from the government. There is no "one size fits all" solution.

In conclusion, wherever there was involvement of commercial banks in coordination and implementation, the level of direct government involvement in coordination and implementation is marked with no or yes + in Table 2. 


\subsection{Focal point}

There is a growing volume of literature on identifying one-stop-shop (OSS) business mechanisms as a supporting arm to bridge the gap between the supply and demand sides on the energy efficiency market (Pandelieva 2011; Mahapatra et al. 2019). The importance of OSS emerges from analysing case studies (Boza-Kiss et al., 2018). The common element in seven of the case studies we evaluated is that there is a focal point in coordination and implementation. The role of the focal point is to distribute grants and guarantees alongside commercial loans.

Table 3

\section{Focal points in coordination and implementation}

\begin{tabular}{cccc}
\hline Categories & $\begin{array}{c}\text { Involvement of } \\
\text { commercial banks } \\
\text { in coordination and } \\
\text { implementation }\end{array}$ & $\begin{array}{c}\text { Direct government } \\
\text { involvement in } \\
\text { coordination and } \\
\text { implementation }\end{array}$ & Focal point \\
\hline $\begin{array}{c}\text { Credit lines from } \\
\text { international financial } \\
\text { institutions (e.g. from } \\
\text { the EBRD or EIB) }\end{array}$ & Yes & No & $\begin{array}{c}\text { International financial } \\
\text { institution's advisory } \\
\text { service and commercial } \\
\text { banks }\end{array}$ \\
\hline $\begin{array}{c}\text { IFC guarantee } \\
\text { programmes (HEECP, } \\
\text { CEEF, etc.) }\end{array}$ & Yes & No & $\begin{array}{c}\text { IFC programme office } \\
\text { and commercial banks }\end{array}$ \\
\hline $\begin{array}{c}\text { Energy efficiency funds } \\
\text { (KredEx, EESRF) }\end{array}$ & Yes & Yes + & $\begin{array}{c}\text { Energy Efficiency } \\
\text { Fund office }\end{array}$ \\
\hline $\begin{array}{c}\text { Federal government } \\
\text { development banks } \\
\text { (KfW) }\end{array}$ & No & Ynd commercial banks \\
\hline $\begin{array}{c}\text { Government loans } \\
\text { (in India) }\end{array}$ & No & Yes ++ & $\begin{array}{c}\text { KfW federal } \\
\text { development bank }\end{array}$ \\
\hline
\end{tabular}

Source: compiled by the author from the case studies

Furthermore, all case studies involved a focal point through which the programme was implemented: that is, through which loans, guarantees and grants were distributed to end-users. Focal points act like a one-stop-shop (OSS) for endusers from this perspective.

In cases where direct government involvement in coordination and implementation is not apparent, where commercial banks are heavily involved and loans are distributed directly through and by the commercial banks, the nature of the focal point is more commercial and private. For example, in the case of credit lines offered by international financial institutions and IFC guarantee programmes, 
the focal point was typically the commercial bank and the international financial institution's advisory service partners, or the IFC's local programme office. In contrast, wherever there was direct involvement in coordination and implementation on the part of national or federal governments, the focal point was typically a public-private partnership entity or an entity that was fully publicly owned: for example, in the case of the EESRF in Bulgaria and KredEx in Estonia, where there is a dedicated fund operating and working together with commercial banks, the focal point was the fund itself, backed by the government (Citynvest, 2015). Furthermore, in the case of the KfW programme and the government programme in India, the focal point was, respectively, the KfW federal development bank and the national government of India (ESMAP, 2018; KfW, 2018).

This analysis shows various models for a focal point or OSS which likely depend on the scale of coordination in loan distribution. The focal point or OSS takes on more of a private and commercial nature whenever commercial banks, jointly with international financial institutions, distribute energy efficiency loans and guarantees with grants, while the OSS constitutes more of a public-private partnership or a fully public entity whenever the level of coordination on the part of national or federal governments is higher.

\subsection{Categorization of success factors}

While success can also be measured by how many eligible households have been reached by these programmes, this study aims to measure success via the absolute number of implementations and the investment volume in energy efficiency achieved by the programme in question.

With this limitation in mind, we found that the twelve programmes included in this study received nearly USD 24 billion funding between 1997 and 2018 and leveraged an estimated of USD 365 billion total volume in energy efficiency investments. All individual programmes were able to mobilize energy efficiency financing, some in significant volumes, achieving their original aims. Furthermore, analysis of the case studies shows that the programmes fall into four categories based on the combination of financial instruments they applied, the type of focal point distributing the funds, and the level of coordination by national governments. 
Table 4

Factors in energy efficiency finance

\begin{tabular}{|c|c|c|c|c|c|}
\hline Categories & $\begin{array}{c}\text { Programme } \\
\text { name }\end{array}$ & $\begin{array}{c}\text { Combination of } \\
\text { finance instruments } \\
1 \text { element }=\text { loan } \\
2 \text { elements = loan } \\
+ \text { grant } \\
3 \text { elements = loan } \\
+ \text { guarantee + grant }\end{array}$ & $\begin{array}{l}\text { Focal point lead } \\
1=\text { private } \\
2=\text { public-private } \\
\quad 3=\text { public }\end{array}$ & $\begin{array}{c}\begin{array}{c}\text { Level of } \\
\text { coordination }\end{array} \\
\begin{array}{c}1=\text { no direct gov. } \\
\text { involvement }\end{array} \\
2=\text { yes }+ \\
3=\text { yes }++ \\
4=\text { yes+++ }\end{array}$ & $\begin{array}{c}\text { Estimated } \\
\text { total EE } \\
\text { investment } \\
\text { volume } \\
\text { in million } \\
\text { USD }\end{array}$ \\
\hline \multirow{4}{*}{ Category I. } & HEECP1-2 & 3 & 1 & 1 & 90 \\
\hline & CEEF & 3 & 1 & 1 & 298 \\
\hline & PF4EE & 3 & 1 & 1 & 1022 \\
\hline & CHUEE & 3 & 1 & 1 & 790 \\
\hline \multirow{4}{*}{ Category II. } & RSEFP & 2 & 1 & 1 & 289 \\
\hline & REECL & 2 & 1 & 1 & 127 \\
\hline & TuREEFF & 2 & 1 & 1 & 492 \\
\hline & BEERECL & 2 & 1 & 1 & 306 \\
\hline \multirow{2}{*}{ Category III. } & EERSF & 3 & 2 & 2 & 43 \\
\hline & KredEx & 3 & 2 & 2 & 325 \\
\hline \multirow{2}{*}{ Category IV. } & IEESP & 3 & 3 & 4 & 200 \\
\hline & EECR & 2 & 3 & 3 & 361400 \\
\hline
\end{tabular}

Source: compiled by the author from the case studies

In Category I, commercial loans were combined with guarantees and grants to address the moral hazard issue and the asymmetric information problem, and the focal point responsible for distribution of funds was mostly provided by participating commercial banks with support from the programme offices of international financial institutions and advisory services. Furthermore, there was no direct involvement of national governments in distributing the funds. In Category II, the only difference from Category I was that the programmes combined commercial loans with grants only, and guarantees were not used at all. For programs in Category III and IV, commercial loans were combined with a guarantee and/or grant element. However, government involvement was medium or high both in the leadership of the focal point and in programme coordination. Further narrowing the categories, two major types of programme structures can be identified: 1) multiple financing elements with private and multilateral level of coordination of the programme and distribution of funds; and 2) similarly multiple financing elements, but with public leadership in distribution and implementation. 
We conclude from this analysis that the key success factors of the programs studied are:

1) that they included at least two, if not all three, elements among commercial loans, guarantees and/or grants; and

2) that they had in place a focal point element (private or public-private partnership) to distribute funds and benefits to the beneficiaries acting as a one-stopshop for the end-user.

The study shows that the presence of all three finance categories in a programme with the combination of a focal point may correlate with higher success of the programme, meaning that more energy efficiency projects were implemented. This is in line with recent literature highlighting many effective policy instruments and arguing for the combination of proven energy efficiency policies to target hard-to-reach markets (Rosenow,, 2017; Boza-Kiss et al., 2013).

\subsection{Matrix of energy efficiency finance programme design}

In order to support the arguments presented in the previous section, this study has developed a matrix for guiding policymakers in designing energy efficiency finance programmes, based on analysis and evaluation of the case studies. One dimension of the matrix shows the level of combination of financial instruments, while the other dimension is the level of coordination in implementation. Under the first dimension there are two categories: market-based instruments such as commercial loans, and financial subsidies where the loan is combined with guarantees and grants (all three being present). Under the second dimension there are the categories of market-level coordination of implementation, where the distribution of funds is led by commercial banks and international financial institutions and where the government is moderately or strongly involved in the distribution of loans and subsidies. The categorization is in line with the categorization shown in Table 4. 
Table 5

Energy efficiency finance programme design matrix

Level of combination of financial instruments

\begin{tabular}{|c|c|c|}
\hline & Market based mechanism & Financial subsidies \\
\hline 苞 & $\begin{array}{l}\text { Category IV. from Table } 4 . \\
\text { Most rarely used model, } \\
\text { investment volume } 35 \text { volatile. }\end{array}$ & $\begin{array}{l}\text { Category III. from Table } 4 . \\
\text { Rarely used model, moderate } \\
\text { volume of energy effkxiency } \\
\text { investment has been mobilized }\end{array}$ \\
\hline$\frac{\grave{y}}{\dot{z}}$ & $\begin{array}{l}\text { Category II.from Table } 4 . \\
\text { Very commonly used model, } \\
\text { high volume of energy } \\
\text { efficiency investement } \\
\text { mobilized }\end{array}$ & $\begin{array}{l}\text { Category I. from Table } 4 \text {. } \\
\text { Most commonly used model, } \\
\text { high volume of energy efficiency } \\
\text { investement mobilized }\end{array}$ \\
\hline
\end{tabular}

Source: compiled by the author from the case studies

The study found that programmes where loans were combined with guarantees and grants and the distribution of funds was led by commercial banks in cooperation with international financial institutions (Category I. box in the matrix) generated the most significant volume of energy efficiency loans. Furthermore, this programme model was the most widely used during the past two decades. Second in line were those programmes where commercial loans were complemented by some form of grant, but not by guarantees, and where implementation was led by the market (Category II. box in the matrix). Similarly to Category I. programmes, this model was also widely used. In comparison, those programmes where all three elements of financial instruments were used and the government was involved in the distribution of funds generated a lesser volume of energy efficiency investments (Category III. box in the matrix). In Category IV we identified two very different programs, of which KfW was highly successful, generating USD 361.4 billion in energy efficiency investments, while IEESP has only just recently started in India. The KfW programme has generated extensive literature discussing the policy lessons (Rosenow, 2013; Thomas et al., 2006). We emphasise here that the KfW programme is an outlier in terms of the investment size it mobilised, considering that the programme received significantly larger amounts of direct government funding compared to other programmes studied in this paper. 


\subsection{Non-financial barriers}

While the financial instruments employed in these programmes aimed to address mostly financial limitations, the distribution mechanism designs were likely to address non-financial barriers as well. For instance, we know that energy efficiency markets are fragmented. One way of addressing this issue is having a third party between the source of funding and the end-user to bridge the gap between the supply and demand sides. Analysis of the case studies suggests that the existence of focal points, which were able to function as a one-stop shop between the fund provider and the end-user, was necessary and essential to make the programmes successful.

The study also shows that overcoming legislative gaps and obstacles embedded in a given national institutional system may prove another non-financial obstacle that needs to be dealt with in order to guarantee the successful upscaling of energy efficiency programmes. We can see from the analysis that in Bulgaria, for example, several energy efficiency programmes were available for nearly two decades; however, the study does not find evidence that trials of a multitude of subsidy instruments, which have delivered elsewhere for long periods of time, were able to mobilize significantly larger volumes of lending for energy efficiency projects on their own compared to other programmes studied in this paper (REECL, 2019; EERSF, 2018; EBRD Citynvest, 2015; EBRD, 2013). In Bulgaria, the existence of adverse legislative and institutional system design might be the reason behind this inconsistency.

For example, in Bulgaria residential housing condominiums cannot access loans as a single entity from commercial banks, unlike in Hungary where they can. Condominium legislation in Hungary was therefore able to better address the market fragmentation issue of residential energy efficiency, compared to Bulgaria where homeowners had to apply for loans individually, and not as a condominium. Furthermore, the Bulgarian institutional system, which was able to form a focal point and one-stop-shop mechanism, was different from other CEE countries. In most CEE countries, the focal point is created and maintained by horizontal cooperation between commercial banks and international financial institutions. In Bulgaria, we witnessed stronger governmental control, similarly to the Estonian KredEx case. The Bulgarian case shows that government involvement in the focal point in itself does not guarantee that market obstacles are effectively overcome, and in some cases might even prove detrimental by crowding out other stakeholders. Compared to the KredEx programme, in Bulgaria neither the energy service companies, nor housing condominiums were able to play a strong role in delivering energy efficiency investments to end-users. 


\section{DISCUSSION}

Existing policies used in energy efficiency programs revolve around addressing the financial barriers to energy efficiency, such as addressing asymmetric information and moral hazard issues, to increase the success potential of energy efficiency projects and reduce the risk of lending, alongside some capacity building support. However, very little effort has been dedicated to addressing the nonfinancial barriers to energy efficiency, an element that has only recently started to emerge in the energy efficiency finance and policy research field.

In this study, through analysing and evaluating twelve case studies, we established different categorizations of energy efficiency finance programmes based on the combination and distribution design of financial instruments. This study shows that all selected case studies were operational for several years, while some are still in operation. All programmes were successful in terms of being able to leverage and mobilize a significant volume of commercial loans from the market. From the technological point of view, the study demonstrates that end-users implemented proven energy efficiency technologies, otherwise the project could not have been funded by commercial loans, given that commercial banks only finance reliable technologies that are well known and accepted on the market. However, due to the limitation on borrowing capacity of end-users and the limited availability of post-implementation energy studies, there is not enough evidence to state that the full energy efficiency potential of these projects was realized.

We found that the financial hurdles were addressed in the case studies by combining commercial loans, on various scales, with grant and guarantee elements to address the moral hazard and asymmetric information problems. In this way, the combination of commercial loans with both guarantees and grants could prove more suitable for addressing market obstacles in a holistic fashion. Providing grants and guarantees jointly reduces the cost of financing and increases the potential of success of energy efficiency investments by decreasing loan default rates, for example. Regarding grants, where the grant is provided in the form of interest-rate subsidies or technical assistance, the cost of financing is reduced and as such the probability of success of energy efficiency investments increases. This mechanism also addresses the moral hazard issue. Therefore, programmes with combined instruments are likely to address moral hazard issues more efficiently. Where the moral hazard is present as a possibility, the market on its own requires an increased level of upfront capital investment to address this issue. This is especially problematic in the residential housing sector, where middle to low-income households in owner-occupied buildings face the financial obstacle of insufficient upfront capital to implement energy efficiency investments. The aim of policymakers, when it comes to the residential sector, should therefore be to minimize 
the moral hazard risks by offering a combination of loan and guarantee instruments to reduce capital requirements from households. However, the case studies demonstrate that guarantees were rarely targeted towards specific areas, such as new technologies, new markets and market niches such as low-income households, where they are most needed.

We also see that, beyond the design of financial instruments, the level of coordination is also a relevant factor. Here we found that where commercial banks were the major focal point of distribution of funds, with the support of donor international financial institutions, the level of government involvement in distribution and implementation was non-existent or limited. On the contrary, where commercial banks were not involved in the distribution of funding, the level of government involvement in coordination was obviously higher. Finally, there were cases where commercial banks were involved in the distribution alongside a public body or a fund which was responsible for coordination, such as in the Bulgarian and Estonian cases; and yet, even in these instances, there remains a question of balance between market actors and the government, as seen in the Bulgarian case where government intervention can be counterproductive. There is enough supporting evidence from the study that the differing level of government involvement in coordination is not an independent variable on its own when it comes to the successful implementation of energy efficiency programmes. Given that around two-thirds of the programmes fall in the first category, where there is no or very limited involvement of national governments in coordination, policymakers might consider prioritizing cost-effective private mechanisms and the distribution of funds via commercial banks, instead of setting up public funds as independent legal entities or distributing via the central government.

The study has shown that addressing non-financial barriers might also contribute to the success of energy efficiency programmes. This study identified that all twelve programmes operated some kind of focal point or one-stop shop. Furthermore, the study detected two major distribution and implementation designs for focal points, either led by private-multilateral partnerships or by public-private partnerships. Where donors provided grants to cover the costs of operation and administration of a programme office or a focal point, grants addressed nonfinancial barriers as well. In a fragmented market such as the energy efficiency market, an intermediary between the fund provider and the end-user helps to address non-financial challenges and close the gap between demand and supply. Policymakers might consider promoting the creation of focal points or one-stop shops to facilitate closing this gap.

The recommendation for policymakers is to combine commercial loans with grants and targeted guarantee instruments. The scale of commercial loans compared to the level of grants and guarantees is recommended to be the highest. 
Where a commercial bank is the major distributor of loans, the recommended level of coordination from the government in implementation is low or limited. Using a focal point or a one-stop-shop instrument is essential to close the gap between the fund provider and the end-user. Based on the case studies, the focal point is likely to be designed as a private-public partnership weighted towards the market-based element. The public side might provide grants for covering the operational costs of the focal point or one-stop shop.

Finally, there is limited literature and data available to evaluate the exact optimum combination of the three financial instruments cited in this paper and to establish a quantitative methodology for measuring the holistic success of these policies in the field of energy efficiency finance, including not only concrete savings and reductions in greenhouse gas emissions, but all related benefits. This study shows that the programmes cited in the case studies were designed to combine loans, grants and guarantees, with loans clearly dominating the model; however, modelling of the various combinations of these instruments and their potentially differing impact on the market and its growth is rarely available.

One reason for this lack of transparency and comparative data could be that the original intent of the given policymaker was to simply set up an energy efficiency programme and see the volume of energy investments it can generate. However, in this scenario, the expected next step should be to derive lessons from these results and improve the programme's design by developing predictive models that are able to measure the success rates of the various combinations of policies and financial instruments employed so far. In contrast, this study shows that most programmes were closed after a relatively short period of time, and that policymakers and financial institutions replicated the same model, without any significant improvement in design, in other countries or markets.

From an academic point of view, it is desirable to draw lessons from these pioneering programmes and develop reliable predictive models when it comes to the optimum combination of financial instruments and optimum level of government involvement in distributing funds via focal points to end-users. Via this process, future programmes would be better fit to serve specific market segments, address market obstacles and upscale energy efficiency investments, even in the most challenging sectors such as the residential building sector. 


\section{CONCLUSION}

This study formulates a categorization of energy efficiency finance programmes based on twelve case studies selected from Central and Eastern Europe, as well as other European countries, in addition to Russia, Turkey, China and India, identifying three major categories. All of the studied energy efficiency programmes provided loans to end-users, with the combination of grants and/or guarantees. The study also identified a focal point of coordination and implementation with the role of distributing grants and guarantees alongside commercial loans, serving as a one-stop-shop instrument to support end-users in the implementation of energy efficiency projects. The presence of all three categories of financial instrument in a single programme, combined with a focal point, may correlate with the higher success of the given programme, meaning that more energy efficiency projects have been implemented in these programmes. Successful energy efficiency programmes were structured around addressing various financial obstacles to energy efficiency, with the different instruments targeting different market needs or failures; however, we also found that addressing non-financial obstacles contributed to the success of those programmes which employed a one-stop-shop instrument. Programmes that fail to reckon with various market needs and failures, as well as with non-financial constraints that can impact their successful implementation, risk undesirable outcomes in terms of both the quantity and quality of projects implemented. Further research is required to understand and quantify the optimum combination of commercial loans, grants and guarantees to be employed in a given programme and the most effective governance and funding structure to be employed in the one-stop-shop instrument intended to complement those financial instruments.

\section{REFERENCES}

Adler, M. (2013): Estonain KredEx fund for Renovation Loans. https://renovate-europe.eu/wp-content/uploads/2015/10/16_M_Adler_REDay2013.pdf. Accessed: o7 July 2020.

Berlinger, E. - Juhász, P. - LovAs, A. (2015): Az állami támogatás hatása a projektfinanszírozásra erkölcsi kockázat és pozitív externáliák mellett [The impact of state support on project financing under moral risk and positive externalities]. Közgazdasági Szemle LXII. February, 139-171, http://www.kszemle.hu/tartalom/cikk.php?id=1533.

BozA-Kiss, B. - Bertoldi, P. (2018): One-stop-shops for energy renovations of buildings, European Commission, Ispra, JRC113301.

Boza-Kiss, B. - Moles-Grueso, S. - Ürge-Vorsatz, D. (2013): Evaluating policy instruments to foster energy efficiency for the sustainable transformation of buildings. Current Opinion in Environmental Sustainability 5(2), 163-176, https://doi.org/10.1016/j.cosust.2013.04.002. 
Build Up European Portal for Energy Efficiency in Buildings (2017):The KredEx Revolving Fund - Estonia. https://www.buildup.eu/en/practices/publications/kredex-revolving-fund-estonia-o. Accessed: 7 July 2020.

Citynvest (2015a): KredEx Revolving Fund for energy efficiency in apartment buildings. http://citynvest.eu/content/kredex-revolving-fund-energy-efficiency-apartment-buildings. Accessed: 07 July 2020.

Citynvest (2015b): Bulgarian Energy Efficiency and Renewable Sources Fund - EERSF (2015): http:// citynvest.eu/content/bulgarian-energy-efficiency-and-renewable-sources-fund-eersf. Accessed: 07 April 2020.

CzAKó, V. (2012): Evolution of Hungarian residential energy efficiency support programmes: road to and operation under the Green Investment Scheme. Energy Efficiency 5, 163-178, https://doi. org/10.1007/s12053-011-9135-5.

EBRD (2013): European Bank for Reconstruction and Development: Case study: Bulgaria: 10 years of EBRD Sustainable Energy Financing Facilities. https://ebrd.com/documents/climate-finance/ get-bulgaria.pdf. Accessed: 05 April 2020.

EBRD (2014): European Bank for Reconstruction and Development: Online information on the Bulgarian Energy Efficiency and Renewable Energy Credit Line. https://www.ebrd.com/news/2014/ beerecl-concludes-on-a-high-note.html. Accessed: 20 July 2020.

EBRD (2019): European Bank for Reconstruction and Development: "Turkish families invest in energy efficient homes". https://www.ebrd.com/news/2019/turkish-families-invest-in-energyefficient-homes.html. Accessed 22 April 2020.

EERSF (2018): Energy Efficiency and Renewable Sources Fund: Online information on the Bulgarian Energy Efficiency and Renewable Sources Fund - EERSF. https://www.bgeef.com/en/. Accessed: 07 April 2020.essed o6 March 2020.

EIB (2019): European Investment Bank: Private Finance for Energy Efficiency (PF4EE). https://www. eib.org/en/products/mandates-partnerships/pf4ee/index.htm. Accessed: o7 July 2020.

EIB (2020): European Investment Bank: Online information on the Private Finance for Energy Efficiency (PF4EE). https://pf4ee.eib.org/. Accessed: o7 July 2020.

ESMAP (2018): Energy Sector Management Assistance Program: India Set for Big Gains through Energy Efficiency. https://www.esmap.org/india_set_for_big_gains_through_energy_efficiency. Accessed: 22 April 2020.

GEF (1997): Global Environment Facility: Hungary Energy Efficiency Co-financing Program. Project Document. https://www.thegef.org/project/energy-efficiency-co-financing-program. Accessed: o7 March 2020.

GEF (2001): Global Environment Facility: Hungary Energy Efficiency Co-financing Program 2. Project Document. https://www.thegef.org/project/energy-efficiency-co-financing-program2-heecp2. Accessed: 12 July 2020.

GEF (2002): Global Environment Facility. Commercializing Energy Efficiency Finance. Project Document. https://www.thegef.org/project/commercializing-energy-efficiency-finance-ceeftranche-i. Accessed: 20 July 2020.

GEF (2004): Global Environment Facility: Russia Sustainable Energy Finance Program. Project Documents. https://www.thegef.org/project/russian-sustainable-energy-finance-program. Accessed: 17 July 2020.

GEF (2012): Global Environment Facility: Transfer of Environmentally Sound Technologies. Case Studies from the GEF Climate Change portfolio. https://www.thegef.org/sites/default/files/publications/GEF-TechTransfer-lowres_final_2.pdf. Accessed: 05 March 2020.

IEA (2014): International Energy Agency Capturing the Multiple Benefits of Energy Efficiency. https://doi.org/10.1787/9789264220720-en. 
IEA (2018): International Energy Agency: Energy Efficiency: The first fuel of a sustainable global energy systems. https://www.iea.org/topics/energy-efficiency.

IEA (2019): International Energy Agency: Energy Efficiency 2019. https://doi.org/10.1787/ef14df7a-en.

IFC (2011): International Finance Corporation: Analysis of international best practice in organizing and financing capital repairs and energy efficiency modernizations of multi-family buildings in Central and Eastern Europe. https://www.ifc.org/wps/wcm/connect/a121979b-4b4c-4193-afib89296c61b140/PublicationRussiaRREP-2011-en.pdf?MOD=AJPERES\&CVID=jwyHSTd. Accessed: 12 March 2020.

IFC (2014a): International Finance Corporation: Terminal evaluation of the Russia sustainable energy finance program (RSEFP) (English) - Executive Summary of Evaluation. http://documents. worldbank.org/curated/en/779361500894037026/Terminal-evaluation-of-the-Russia-sustainable-energy-finance-program-RSEFP. Accessed: 12 March 2020.

IFC (2014b): International Finance Institution: Summary of Project Information. http://ifcext.ifc. org/ifcext/spiwebsite1.nsf/DocsByUNIDForPrint/458240222C77EB90852576C10080CB59?open document. Accessed: 14 March 2020.

IPCC (2007): Intergovernmental Panel on Climate Change: Summary for Policymakers. In: Metz, B. et al. [eds.] (2007): Climate Change 2007: Mitigation. Contribution of the Working Group III. to the Fourth Assessment Report of the Intergovernmental Panel on Climate Change. Cambridge, United Kingdom and New York, NY, USA: Cambridge University Press. http://www.ipcc-wg3. de/publications/assessmentreports/ar4/.files-ar4/SPM.pdf. Accessed: 05 March 2020.

IPCC (2014): International Panel on Climate Change: Summary for Policymakers. In EdenHofer, O. et al. [eds.] (2014): Climate Change 2014: Mitigation of Climate Change. Contribution of Working Group III to the Fifth Assessment Report of the Intergovernmental Panel on Climate Change. Cambridge University Press, Cambridge, United Kingdom and New York, NY, USA. https://www.ipcc.ch/site/assets/uploads/2018/o2/ipcc_wg3_ar5_summary-for-policymakers. pdf. Accessed: 05 March 2020.

KfW (2017): Kreditanstalt für Wiederaufbau (“Credit Institute for Reconstruction”) Ten years of the KfW's "Energy-efficient Construction and Refurbishment” programmes. Press Release from 2017-03-13 / Group, KfW Research, Domestic Promotion. https://www.kfw.de/KfW-Group/ Newsroom/Latest-News/Pressemitteilungen-Details_40320o.html. Accessed: 10 March 2020.

KfW (2018): Kreditanstalt für Wiederaufbau (“Credit Institute for Reconstruction”) KfW's programmes for energy-efficient construction and refurbishment have positive impacts on the climate and public coffers. Press Release from 2018-06-04 / Group, KfW Research. https://www. kfw.de/KfW-Group/Newsroom/Latest-News/Pressemitteilungen-Details_472512.html. Accessed: 10 March 2020.

Levine, M. - Ürge-Vorsatz, D. - Blok, K. - Geng, L. - Harvey, D, - Lang, S. et al. (2007): Residential and commercial buildings. In Metz, B. et al. [eds] (2007): Climate Change: Mitigation. Contribution of Working Group III. to the Fourth Assessment Report of the Intergovernmental Panel on Climate Change. Cambridge: Cambridge University Press.

Mahapatra, K. - Maindali, B. - Pardalis, G. (2019): Homeowners' attitude towards one-stopshop business concept for energy renovation of detached houses in Kronoberg, Sweden. In Energy Procedia 158, 3702-3708. https://doi.org/10.1016/j.egypro.2019.01.888.

Pandelieva, I. (2011) Creation of one-stop-shop to boost investment in energy efficiency in Rhodope region, Bulgaria. 17th International Multidisciplinary Scientific GeoConference. https:// doi.org/10.5593/sgem2017/54/s23.034.

REECL (2019): Residential Energy Efficiency Credit Line. Online information on the Residential Energy Efficiency Credit Line. http:/reecl.org/en/about-us/. Accessed: 20 July 2020. 
Rosenow, J. (2018): Addressing the non-financial barriers - making energy efficiency finance work. $\mathrm{C}_{4} \mathrm{E}$ Forum: https://www.raponline.org/wp-content/uploads/2018/o6/rap-rosenow-C4E-Nonfinancial-barriers-2018-june.pdf. Accessed: 05 March 2020.

Rosenow, J. - Kern, F. - Rogge, K. (2017): The need for comprehensive and well targeted instrument mixes to stimulate energy transitions: The case of energy efficiency policy. Energy Research \& Social Science 33, 95-104, https://doi.org/10.1016/j.erss.2017.09.013.

Rosenow, J . (2013): The politics of the German $\mathrm{CO}_{2}$-Building Rehabilitation Programme. Energy Efficiency 6(2), 219-238, https://doi.org/10.1007/s12053-012-9181-7.

Taylor, R. - Govindarajalu, C. - Levin, J. - Meyer, A. - Ward, W. (2008): Financing Energy Efficiency - Lessons from Brazil, China, India, and Beyond. In World Bank Books, https://doi. org/10.1596/978-0-8213-7304-0.

Thomas, S. - Suerkemper, F. - Adisorn, T. - Hauptstock, D. - SchäferSparenberg, C. - Tholen, L. - Vondung, F. - Becker, D. - Tesniere, L. - Bourgault, C. - Förster, S. (2016): Energy Efficiency Policies in Europe: KfW Programme - Germany. In Energy Efficiency Watch, https://www.greengrowthknowledge.org/case-studies/energy-efficiency-policies-europe-kfwprogramme-germany. Accessed: 03 March, 2020.

TuREEFF (2018): Turkish Residential Energy Efficiency Facility: Online information available on TuREEFF. https://www.tureeff.org/hakkimizda?lang=en. Accessed: 14 Aril 2020.

UN (2015): United Nations: The Paris Agreement. https://unfccc.int/files/essential_background/convention/application/pdf/english_paris_agreement.pdf. Accessed: 06 March 2020.

UN (2020): United Nations: Best practices on standards and technologies for energy efficiency in buildings. In ECE Energy Series, 41-56, https://doi.org/10.18356/e90569a8-en.

UNEP (2019): United Nation Environmental Program: Emission Gap Report 2018. https://doi. org/10.18356/7d 33498d-en.

Ürge-Vorsatz, D. - Herrero, T. - Dubash, K. - Lecocq, F. (2014): Measuring the Co-Benefits of Climate Change Mitigation. Annual Review of Environment and Resources 39(1) 549-582, https:// doi.org/10.1146/annurev-environ-031312-125456.

Ürge-Vorsatz, D. - Novikova, A. - Sharmina, M. (2009): Counting good: Quantifying the cobenefits of improved efficiency in buildings. ECEEE Summer Study, https:/www.ceu.hu/sites/ default/files/publications/eceee20o9paper2316cobenefitsurgenovikovasharmina.pdf. Accessed: 05 March 2020.

Ürge-Vorsatz, D. - Metz, B. (2009): Energy efficiency: how far does it get us in controlling climate change? Energy Efficiency 2(2), 87-94, https://doi.org/10.1007/s12053-009-9049-7.

Ürge-Vorsatz, D. - Novikova, A. (2008): Potentials and costs of carbon dioxide mitigation in the world's buildings. Energy Policy 36(2), 642-661, https://doi.org/10.1016/j.enpol.2007.10.009.

World Bank (2010): Energy Efficiency Finance Assessing the Impact of IFC's China Utility-Based Energy Efficiency Finance Program, https://doi.org/10.1596/978-0-8213-8450-3.

World Bank (2018): Project Signing: Government of India, EESL and World Bank Sign \$30o Million Agreement to Scale Up India's Energy Efficiency Program. https://www.worldbank.org/ en/news/press-release/2018/08/28/agreement-scale-up-indias-energy-efficiency-program. Accessed: 20 March 2020.

World Bank (2019): India Energy Efficiency Scale Up Program, Implementation Status and Results. https://projects.worldbank.org/en/projects-operations/document-detail/P162849. Accessed: 20 March 2020. 